http://jmscr.igmpublication.org/home/ ISSN (e)-2347-176x ISSN (p) 2455-0450 crossref DOI: https://dx.doi.org/10.18535/jmscr/v8i8.51

\title{
To compare the effect of Platelet Rich Plasma over conservative treatment in grade 3 ATFL tear: Prospective Interventional Study
}

Authors

\author{
Dr Shikha Dhaundiyal ${ }^{1}$, Dr Deepak Joshi ${ }^{2}$, Dr Gaurav Chawla ${ }^{3}$ \\ ${ }^{1}$ Senior Resident (MD Sports Medicine) Gold Medalist Sports Injury Centre, VMMC \& SJH \\ ${ }^{2}$ Senior Specialist Sports Injury Centre, VMMC \& SJH \\ ${ }^{3}$ MBBS (SJH) Ex Mo Urology Ex Intensivist Delhi Health Service (DHS)
}

\section{Introduction}

Lateral ankle sprain (LAS) is the most common musculoskeletal injury in the physically active population; it is also a common condition in the general population. Apart from the pain and temporary period of reduced functioning and disability, it is also associated with increased risk of recurrence ankle instability. ${ }^{[1]}$

Repeated episodes of supination on an externally rotated rear foot predisposes to lateral ankle sprains. Recurrent ankle sprain mostly common in a patient with chronic ankle instability which could be mechanical due to lax ligament or multi-ligament instability, biomechanical error, degenerative changes in joints or ligament. Functional instability due to error in proprioception and neuromuscular control. ${ }^{[2]}$

LAS is hypothesised to cause Functional instability (FI) following repeated injury predispose individuals to neuromuscular deficits. LAS not only cause structural damage to the ligamentous tissue, but also to the nervous and musculotendinous tissue around the ankle complex. Ligaments injury leads to laxity of the joints of the ankle complex, may also compromise neuromuscular complex due to the injury to the nervous and musculotendinous tissue. These neuromuscular deficits may be manifested as impaired balance, reduced joint position sense, slower firing of the peroneal muscles to inversion perturbation of the ankle, slowed nerve conduction velocity, impaired cutaneous sensation, strength deficits and decreased dorsiflexion range of motion. ${ }^{[3]}$

\section{Platelet Rich Plasma}

Platelet-rich plasma (PRP) is an autologous concentration of human platelets in a small volume of plasma obtained by sequestering and concentrating platelets by gradient density centrifugation. This technique produced a concentration of human platelets of $338 \%$ and identified platelet-derived growth factor and transforming growth factor beta within them. Therefore, the term PRP is preferred to autologous platelet gel, plasma-rich growth factors (PRGFs), or a mere autologous platelet concentrate. Because it is a concentration of platelets. It is also a concentration of the 7 fundamental protein growth factors proved to be actively secreted by platelets to initiate all wound healing. These growth factors include the 3 isomeres of platelet-derived growth factor (PDGF alpha alpha, PDGF beta beta, and PDGF alpha beta), 2 of the numerous transforming growth factors- (TGF1 and TGF2), vascular 
endothelial growth factor, and epithelial growth factor. ${ }^{[4]}$

Platelet concentrates into four categories, depending on their leucocyte and fibrin content: pure platelet-rich plasma (P-PRP), such as cell separator PRP, Vivostat PRF or Anitua's PRGF; leucocyte- and platelet-rich plasma (L-PRP), such as Curasan, Regen, Plateltex, Smart PReP, PCCS, Magellan or GPS PRP; pure plaletet-rich fibrin (P-PRF), such as Fibrinet; and leucocyte- and platelet-rich fibrin (L-PRF), such as Choukroun's PRF. [5]

Platelet-rich plasma is just that; it is a volume of autologous plasma that has a platelet concentration above baseline. Normal platelet counts in blood range between $150,000 / \mu 1$ and $350,000 / \mu 1$ and average about 200,000/ $\mu$ l. Because the scientific proof of bone and soft tissue healing enhancement has been shown using PRP with 1,000,000 platelets $/ \mu 1$, it is this concentration of platelets in a 5-ml volume of plasma which is the working definition of PRP today. Lesser concentrations cannot be relied upon to enhance wound healing, and greater concentrations have not yet been shown to further enhance wound healing.

Because PRP is developed from autologous blood, it is inherently safe and is free from transmissible diseases such as HIV and hepatitis. ${ }^{[6]}$

IOC Consensus paper on use of Platelet rich plasma classified into four categories depending on their leucocyte and fibrin content:

- Pure platelet-rich plasma(P-PRP),

- Leucocyte and platelet rich plasma (L-PRP),

- Pure platelet rich fibrin(L-PRF) and

- Leucocyte and platelet rich fibrin(L-PRF).

Platelets contain alpha granules that is rich in various growth factors like vascular endothelial growth factors (VEGF), epidermal growth factors (EGF), platelet derived growth factors(PDGF), insulin like growth factor (IGF), transforming growth factor (TGF) and interleukin (IL) which helps in healing of injured tissue.

- Apart from high platelet concentration, PRP also contains range of growth factors, chemokines, cytokines. The presence and absence of leucocytes and its activation may determine the type of PRP.

- Platelet number more is not necessarily better $1.5 \mathrm{million} / \mathrm{ul}$ may be optimal "above this has a catabolic effect".

- A concentration of $1,000,000$ platelets/ $\mu \mathrm{L}$ has been suggested to be the working definition of PRP; this represents a platelet concentration five times higher than that of whole blood.

- Autologous platelet rich clots when administered in-vitro promote tendon healing by inducing cell proliferation and by angiogenesis promoting growth factors.

\section{Aims and Objectives \\ Primary Objective}

- To compare the effect of PRP over conservative treatment in ATFL tear

\section{Secondary Objective}

- To study the effect of PRP In ATFL tear

- To study the effect of conservative treatment in ATFL tear

- To study adverse effect of PRP if any

\section{Material and Method}

The study is conducted in outpatient department of Sport's Injury Centre, VMMC and Safdarjung Hospital, New Delhi. This study will include the patients diagnosed with grade 3 ATFL tear were randomized at Sports Injury Centre, VMMC and Safdarjung hospital. Patients above 30 years of age with symptomatic ankle pain clinically evidence of grade 3 ATFL tear were considered. The patient will be enrolled prospectively in the study. Study will be performed on 40 consecutive patients of ATFL tear and fulfilling the inclusion and exclusion criteria.

\section{Methodology}

Study will be carried out in 40 patients with symptomatic grade 3 tear of ATFL of one or both ankle joints who presented during the period of study falls into inclusion criteria and given injection PRP were included as study sample.The 
patients will be divided into two groups, A and B. Block randomization process will be used wherein 2 labeled envelopes will determine group allocation. First subject picks one out of 2 envelopes and is allocated accordingly. Next subject is allocated the remaining envelope.

Group A (Control Group) will receive conservative treatment including NSAIDS +home based exercises including ankle strengthening.

Group B patients will receive an additional intervention in the form of PRP injection.

\section{Pre-Procedural Work Up}

Patients were randomized to receive either PRP injection therapy or to a control group Randomization was performed according to a block randomization method with a block size of two and an allocation ratio of 1:1. The first patient in the study and the first patient in every block were randomized to one of the two study arms. The next diagnosed patient in the block was automatically allocated to the other study arm.

Group A: The treatment group received 3 injections at 4 weekly interval, one at the initial presentation, followed by a rehabilitation programme.

Group B: The control group received the rehabilitation programme.

\section{PRP preparation and injection technique}

A total of $20 \mathrm{ml}$ of peripheral blood was drawn from each patient into four $5 \mathrm{ml}$ trisodium citrate tubes, and a PRGF concentrate was prepared using a validated method resulting in a 29-39 fold increase in platelet concentration without leucocytes.

Tubes were centrifuged with a single spin, at 2500 RPM for $10 \mathrm{~min}$. Under laminar airflow, the plasma fraction located just above the buffy coat $(1.5 \mathrm{~mL})$ was aspirated from each tube and dispensed into an emptytube. The activated concentrate was then injected before coagulation into the ATFL using a 21-gauge needle under aseptic precaution.
Data collection prior to PRP injection includes detailed history, clinical examination and radiological evaluation of patients satisfying the inclusion criteria. Special emphasis on following points during history taking:
1. Age
2. Sex
3. Site of ankle-right/left/bilateral
4. FADI score
5. To assess level of pain (VAS scoring)

\section{Inclusion Criteria}

1) Presence of a ankle sprain with pain and tenderness over the ATFL verified by a positive squeeze test reproducing pain over the ATFL positive Anterior Drawer test, CT or MRI.

\section{Exclusion Criteria}

1) Presence of gross syndesmotic instability presenting as frank diastasis on plain radiographs, previous surgery, or any pre-existing symptoms of ankle instability.

\section{Study Plan}

\begin{tabular}{|c|c|}
\hline $\begin{array}{l}\text { Type of Study } \\
\text { Randomized }\end{array}$ & $\begin{array}{c}\text { Prospective Interventional } \\
\text { Comparative Study }\end{array}$ \\
\hline Period of Study & 6 months \\
\hline Allocation & - Block randomization \\
\hline End point classification & $\begin{array}{ll}- & \text { Efficacy Study } \\
\end{array}$ \\
\hline Primary purpose - & Treatment \\
\hline $\begin{array}{l}\text { Study population - } \\
\text { department and diagnos } \\
\text { on MRI }\end{array}$ & $\begin{array}{l}\text { Patients visiting the } \\
\text { sed with grade } 3 \text { ATFL tear }\end{array}$ \\
\hline
\end{tabular}

\section{Sample Size}

The study observed the difference in mean outcome scores between groups was, with regard to ankle pain, a visual analog scale (VAS) score of 3 points ( $95 \%$ confidence interval $[95 \% \mathrm{CI}],-6$ to 11 points); with regard to ankle function. Taking these values as reference, the minimum required sample size with $90 \%$ power of study and $5 \%$ level of significance is 20 patients in each study group. To reduce margin of error, total sample size taken is 40 (20 patients per group). 
Outline Plan of study

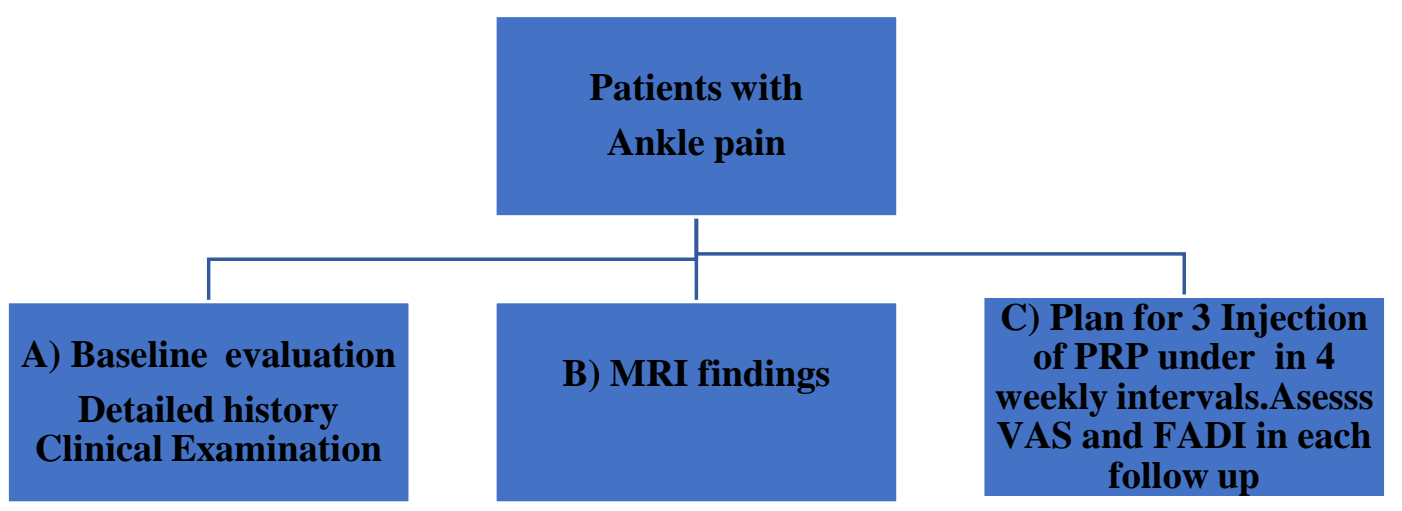

\section{Rehabilitation protocol and follow-up}

Both groups followed the same rehabilitation protocol and were evaluated with the same RTP criteria. Following the first injection or after the initial diagnosis for control, all patients were immobilized in a walking boot in 10plantar flexion and were mobilized non-weight bearing for the first 07 days. The ankle position was dorsiflexed to neutral after 3-4 days. Progressive weight bearing was permitted from days 11-13. After 2 weeks, unrestricted weight bearing was permitted. All patients then followed the same physical therapy protocol of range of movement exercises, proprioception, peroneal strengthening, and functional rehabilitation. Patients were instructed to avoid dorsiflexion activities for 3 weeks from the time of injury and specifically to avoid landing on a bent knee and ankle joint, as well as cutting/pivoting movements.

Clinical evaluations were performed at 3 weeks postinjury: palpation for tenderness and the calf compression test (squeeze test). Patients who had no tenderness were pain-free with weight bearing underwent plantarflexion tests

\section{Statistical Analysis}

Categorical variables will be presented in number and percentage (\%) and continuous variables will be presented as mean \pm SD and median. Normality of data will be tested by Kolmogorov-Smirnov test.
If the normality is rejected then non parametric test will be used.

Statistical tests will be applied as follows-

1.Quantitative variables will be compared using Unpaired t-test/Mann-Whitney Test (when the data sets were not normally distributed.) between the two groups and Paired t-test/ Wilcoxon ranked sum test within the groups across follow-ups.

2.Qualitative variable will be compared using Chi-Square test /Fisher's exact test.

A p value of $<0.05$ will be considered statistically significant.

The data will be entered in MS EXCEL spreadsheet and analysis will be done using Statistical Package for Social Sciences (SPSS) version 21.0.

\section{Results}

Demographic Profile: A total of 20 patients between the age of 20-40 years were enrolled in this study which were divided in two groups. Patients from all socio-economic status and all professions were included in this study.

Gender Ratio: In this study each group contains 20 patients in which Group A contains 8 females (40\%) and 12 males (60\%) and group B contain 06 females $(30 \%)$ and 14 males $(70 \%)$ 


\begin{tabular}{|c|c|c|c|c|c|}
\hline & \multicolumn{2}{|c|}{ GROUP } & \multirow{2}{*}{ Total } & \multirow{2}{*}{$P$ value } \\
\hline & & A & B & & \\
\hline \multirow[t]{2}{*}{ Sex } & $\mathrm{F}$ & $40 \%$ & $30 \%$ & $14(35.00 \%)$ & \multirow[t]{3}{*}{0.520} \\
\hline & $\mathrm{M}$ & $60 \%$ & $70 \%$ & $26(65.00 \%)$ & \\
\hline \multicolumn{2}{|c|}{ Total } & $\begin{array}{c}20 \\
(100.00 \%)\end{array}$ & $\begin{array}{c}20 \\
(100.00 \%)\end{array}$ & $40(100.00 \%)$ & \\
\hline
\end{tabular}

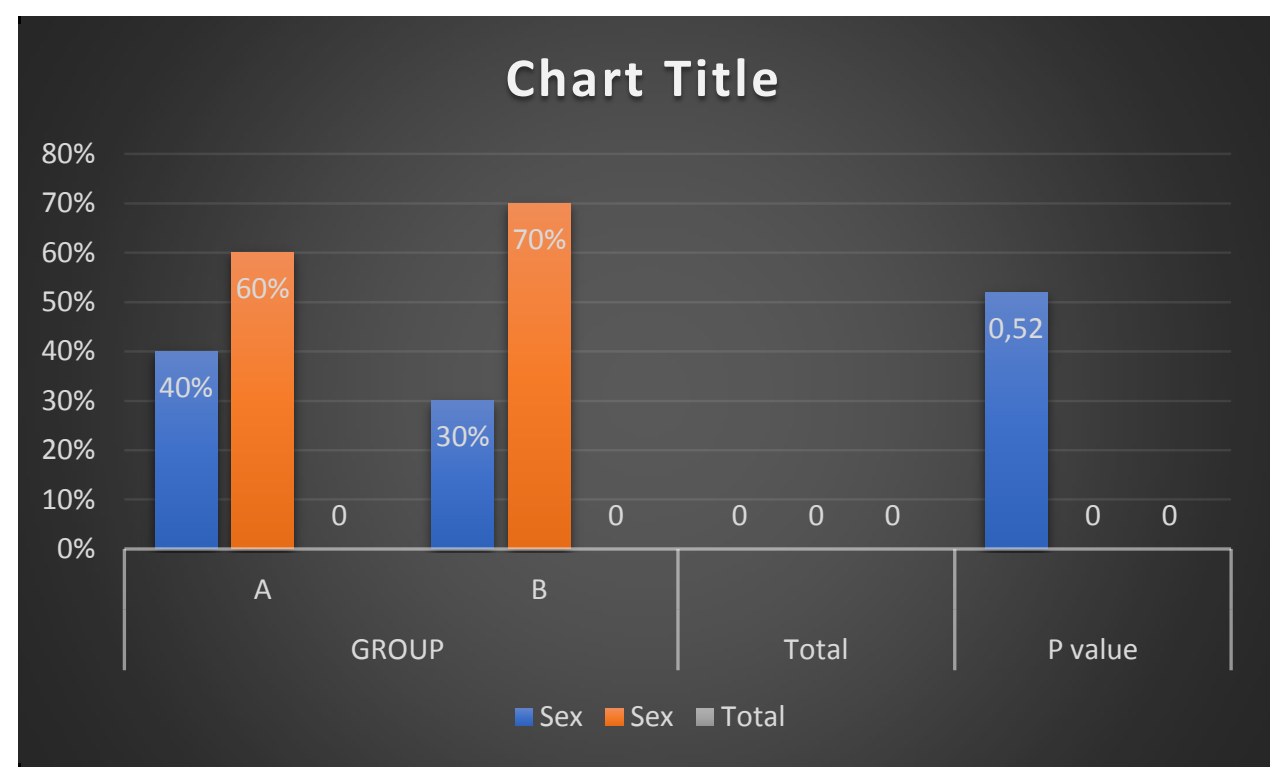

\section{Age Distribution}

Most of the patients belongs to age group of 20-40 years. In the group A 14 (70\%) were of 20-30 age group and $6(30 \%)$ of 31-40 age group and in group B was $15(75 \%)$ were of $20-30$ age group and $5(25 \%)$ were of $30-40$ age group.

\begin{tabular}{|l|c|c|c|c|c|}
\hline \multicolumn{2}{|c|}{} & A & B & Total & P value \\
\hline \multirow{2}{*}{ Age } & $1) 20-30$ & $70 \%$ & $75 \%$ & $29(72.50 \%)$ & \multirow{2}{*}{0.521} \\
\cline { 2 - 5 } & $2) 31-40$ & $30 \%$ & $25 \%$ & $11(27.5 .00 \%)$ & \\
\multirow{2}{*}{ Total } & $\begin{array}{c}20 \\
(100.00 \%)\end{array}$ & $\begin{array}{c}20 \\
(100.00 \%)\end{array}$ & $40(100.00 \%)$ & \\
\hline
\end{tabular}

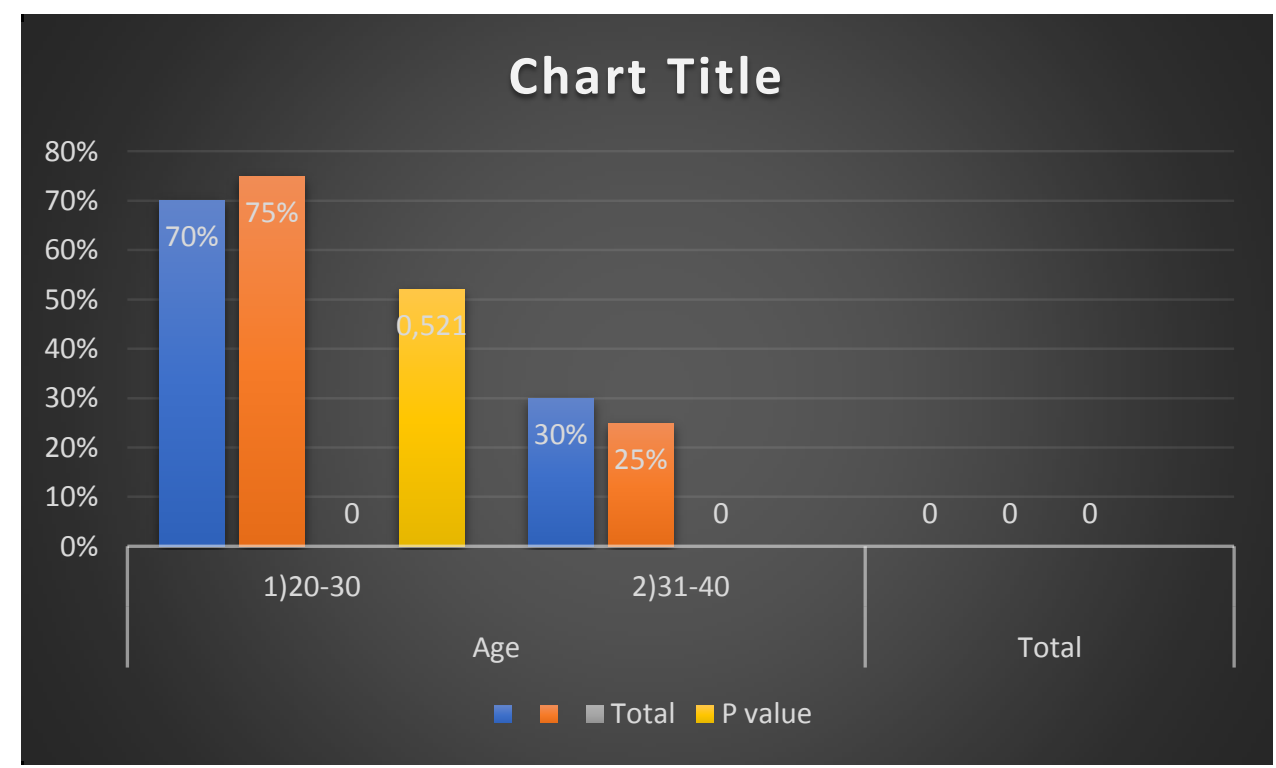




\section{Conclusion}

This study is a single centre, randomized, interventional study in which total 20 pts were selected from OPD of SIC,SJH \& divided into 2 groups using block randomization technique.

\section{VAS Trend}

VAS Trend: At time of intervention the range of VAS in group A was $8.2 \pm 0.9$ which significantly reduces on further follow up at 4,6.12 \& 24 weeks $(6.6 \pm 0.62, \quad 5.1 \pm 0.9, \quad 4.0 \pm 0.92,2.8 \pm 0.8)$. P value on comparing baseline to $4,6,12 \& 24$ weeks was $<.0001$ which can be taken as statistically significant. Subsequent comparison of 4-6 weeks, 6-12 weeks \& 12-24 weeks also shows the $\mathrm{P}$ value $<.0001$.

Similarly in group B mean value of VAS at time of intervention was $7.9 \pm 1.1$ which significantly reduces on further follow up at 4,6.12 \& 24 weeks ( $6.0 \pm 1.0,4.1 \pm 1.0,2.8 \pm 0.8,1.8 \pm 0.4)$. $\mathrm{P}$ value on comparing baseline to $4,6.12 \& 24$ weeks was < .0001 which can be taken as statistically significant. Subsequent comparison of 4-6 weeks, 6-12 weeks \& 12-24 weeks also shows the P value $<.0001$.

\section{Group A}

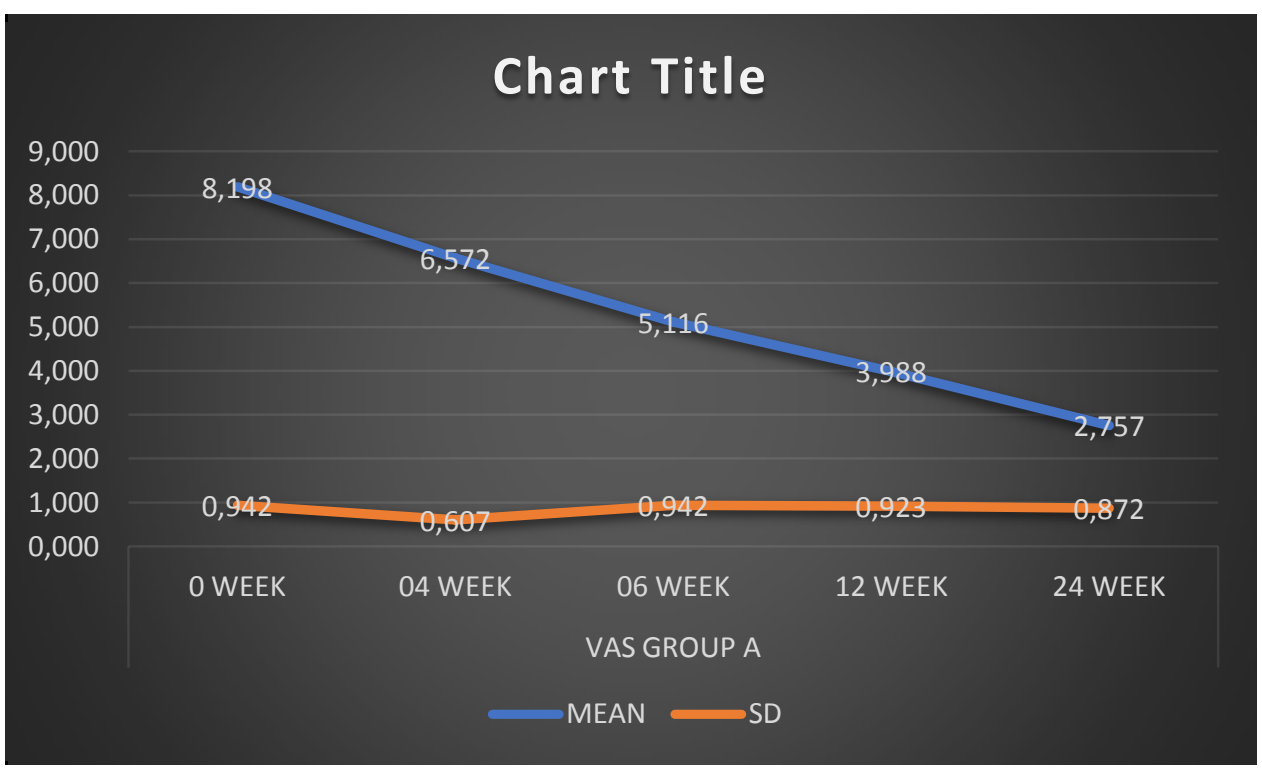

\section{Group B}

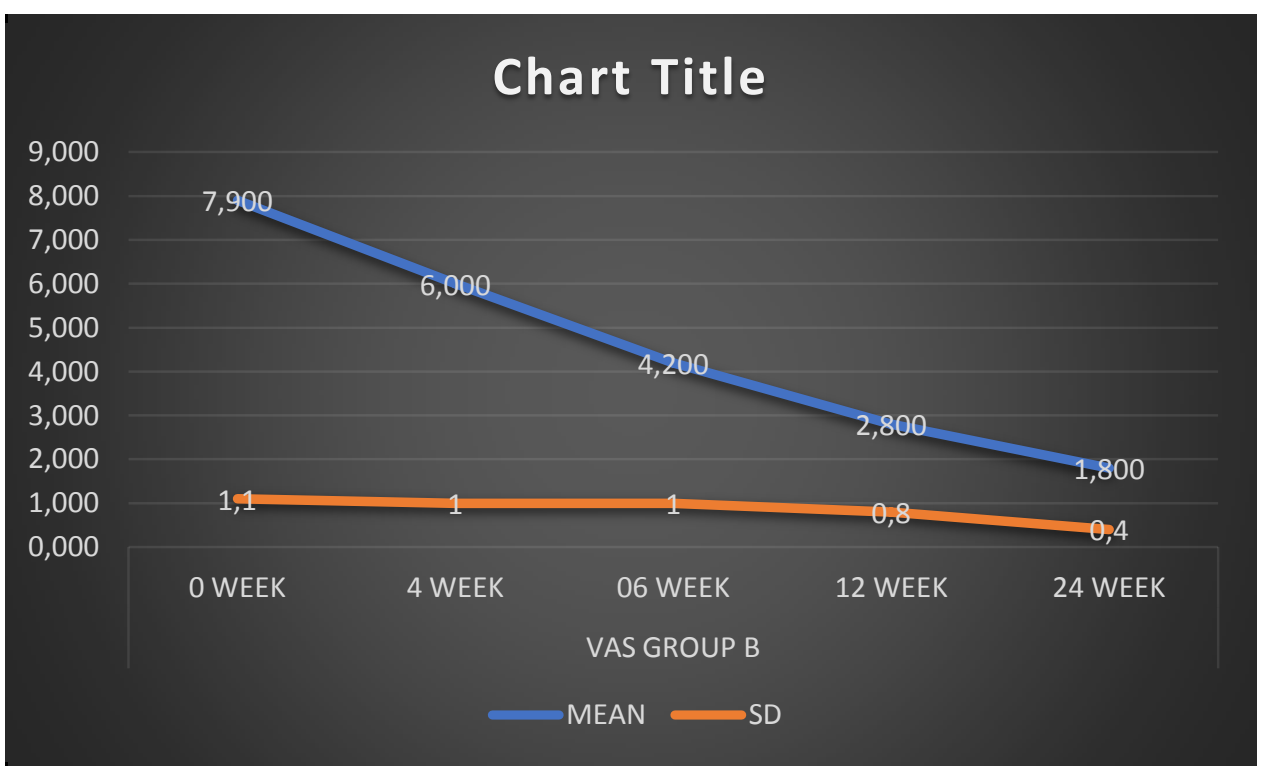




\section{Comparison of Group A and B VAS Trend}
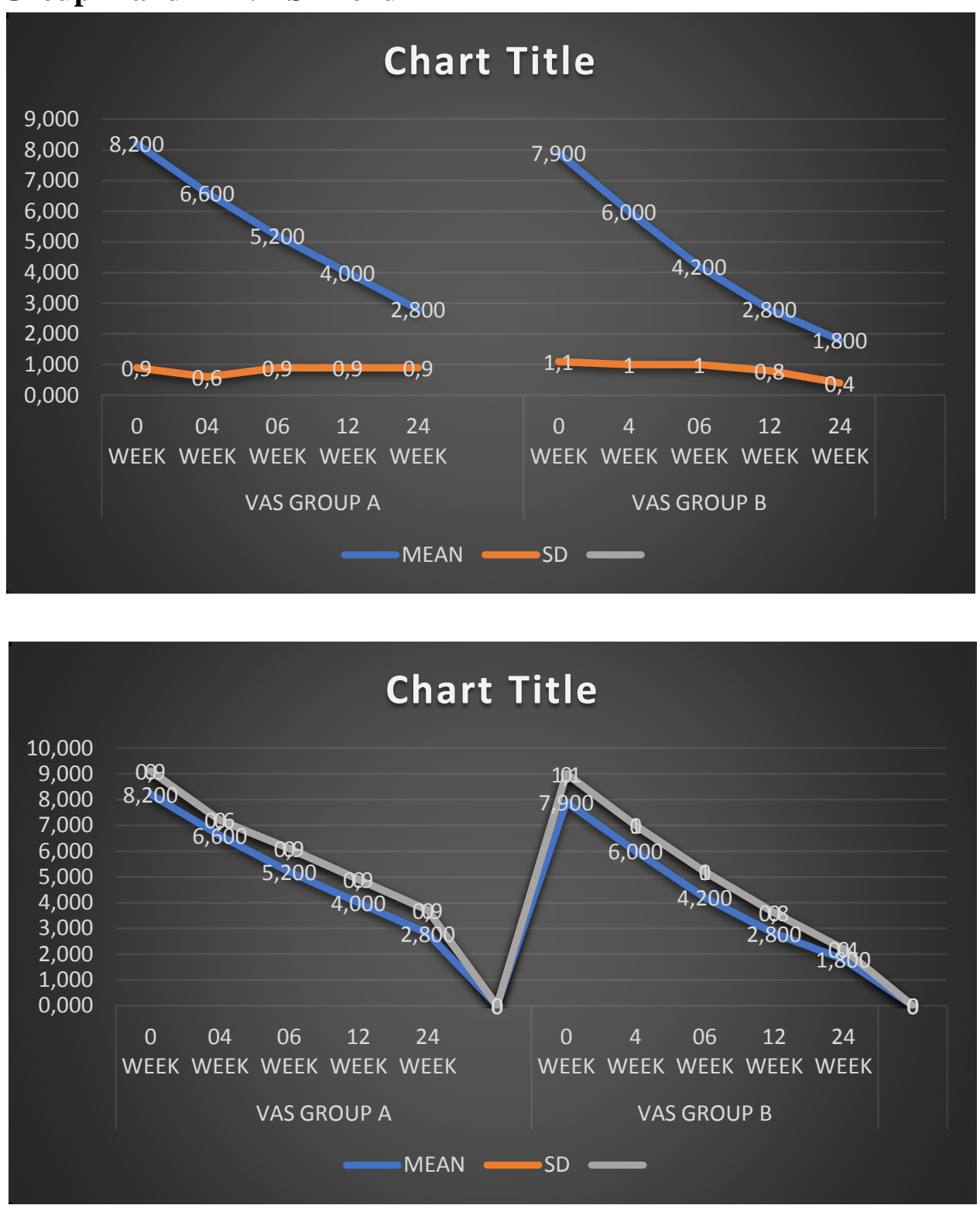

\begin{tabular}{|c|c|c|}
\hline VAS & GROUP A & GROUP B \\
\hline O WEEK of Intervention & $8.198+-0.942$ & $7.881+-1.078$ \\
\hline $04^{\text {th }} \quad$ WEEK & $6.572+-0.607$ & $6.023+-0.998$ \\
\hline $06^{\text {th }}$ WEEK & $5.116+-0.942$ & $4.120+-0.985$ \\
\hline $12^{\text {th }}$ WEEK & $3.988+-0.923$ & $2.805+-0.427$ \\
\hline $24^{\text {th }}$ WEEK & $2.757+-0.872$ & $1.777+-0.427$ \\
\hline
\end{tabular}

\section{FADI Trend}

At time of intervention the range of FADI in group A was $124.6 \pm 6.16$ which significantly reduces on further follow up at 4,6,12 \& 24 weeks (112 \pm $7.89,92.50 \pm 11.02,78.6 \pm 10.56$ and $65.50 \pm$ 10.85). $\mathrm{P}$ value on comparing baseline to $4,6,12 \&$ 24 weeks was $<.0001$ which can be taken as statistically significant. Subsequent comparison of 2-4 weeks, 2-12 weeks \& 4-12 weeks also shows the $\mathrm{P}$ value <.0001.
Similarly in group B mean value of FADI at time of intervention was $124.6 \pm 6.16$ which significantly reduces on further follow up at $4,6,12 \& 24$ weeks $(102 \pm 5.65,81.4 \pm 6.60,67.8 \pm$ 6.05 and $54.7 \pm 6.77$. $\mathrm{P}$ value on comparing baseline to 4,6,12 \& 24 weeks was $<.0001$ which can be taken as statistically significant. Subsequent comparison of 4-6 weeks, 6-12 weeks \& 12-24 weeks also shows the $\mathrm{P}$ value $<.0001$. 
On comparing group A to group B there was AND $24^{\text {th }}$ weeks in favouring of group B statistically significant difference found at 4, 6, 12

\begin{tabular}{|l|c|c|}
\hline WEEKS & FADI GROUP A & FADI GROUP B \\
\hline At the time of intervention & $124.64+-6.16$ & $124.64+-6.16$ \\
\hline $4^{\text {th }}$ WEEK post injection & $112+-7.89$ & $102+-5.65$ \\
\hline $6^{\text {th }}$ WEEK post injection & $92.5+-11.02$ & $81.4+-6.60$ \\
\hline $12^{\text {th }}$ WEEK post injection & $78.6+-10.56$ & $67.8+-6.05$ \\
\hline $24^{\text {th }}$ WEEK post injection & $65.5+-10.85$ & $54.7+-6.77$ \\
\hline
\end{tabular}

\section{Group A FADI Trend}

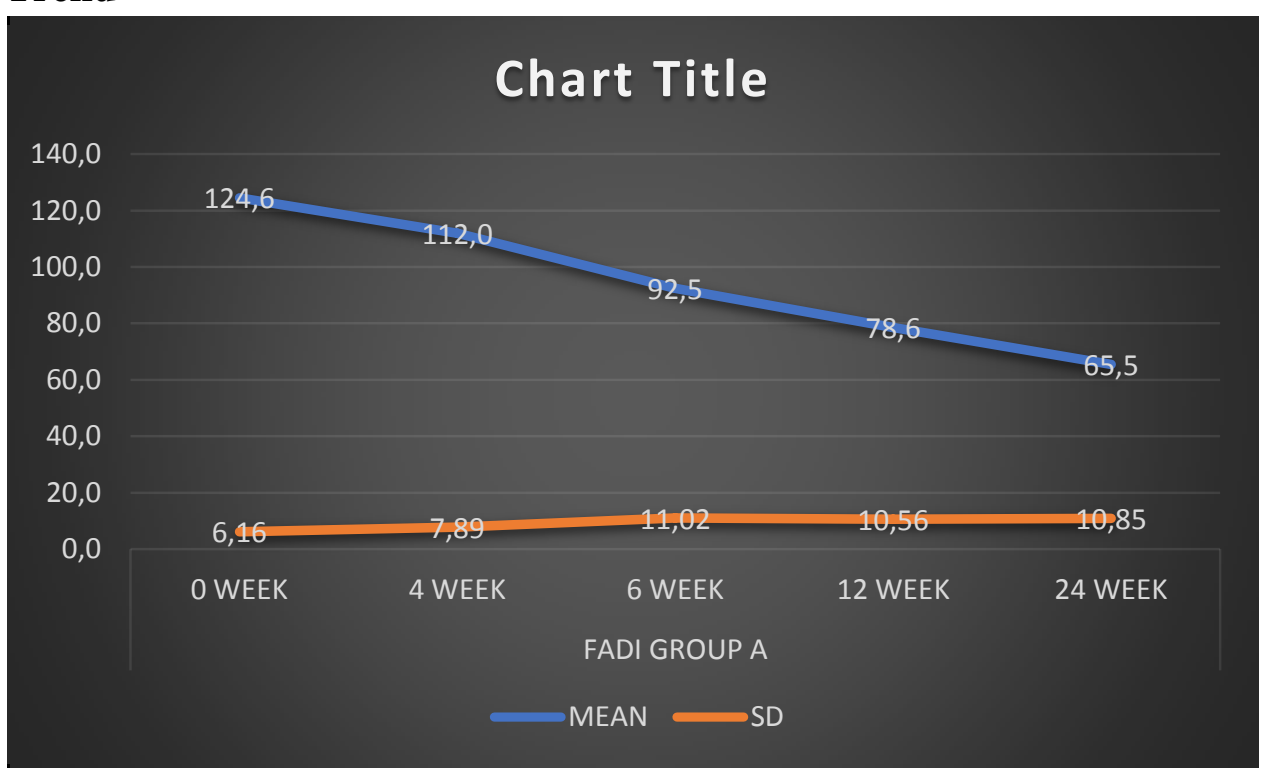

\section{Group B FADI Trend}

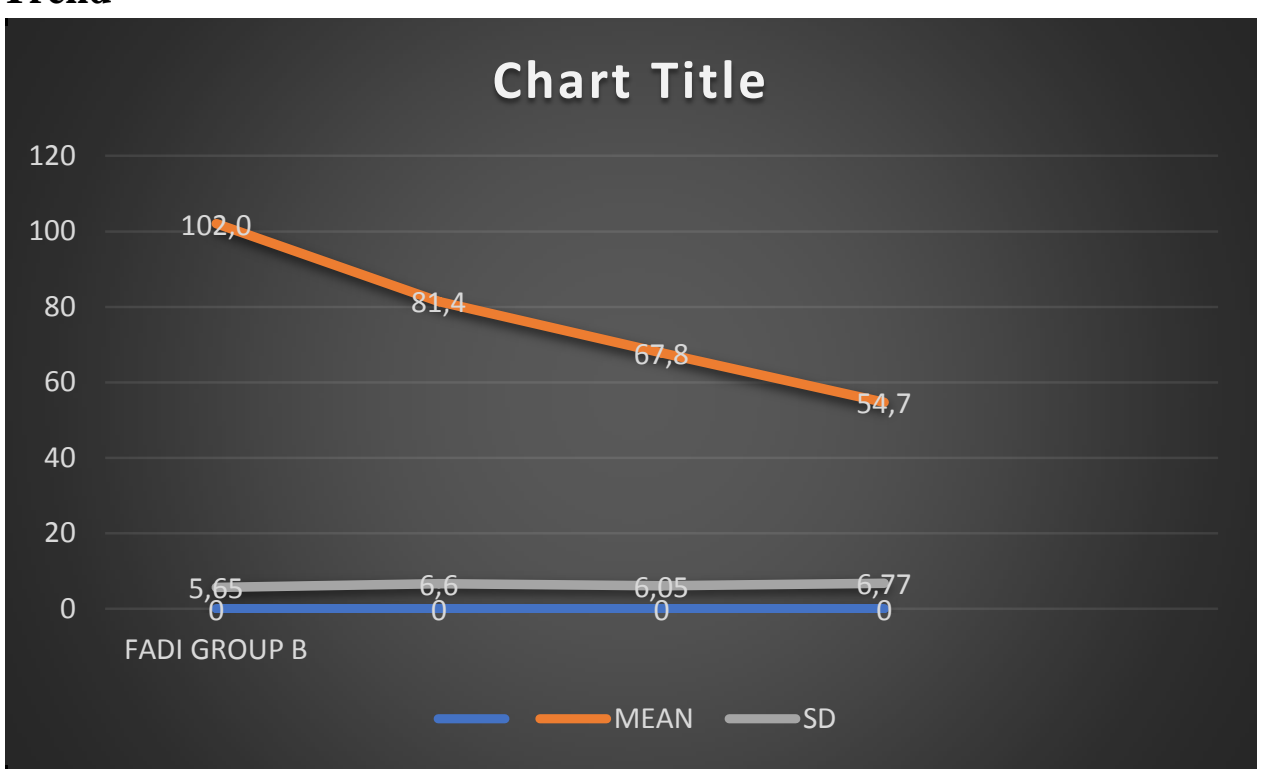




\section{Combined Trend}
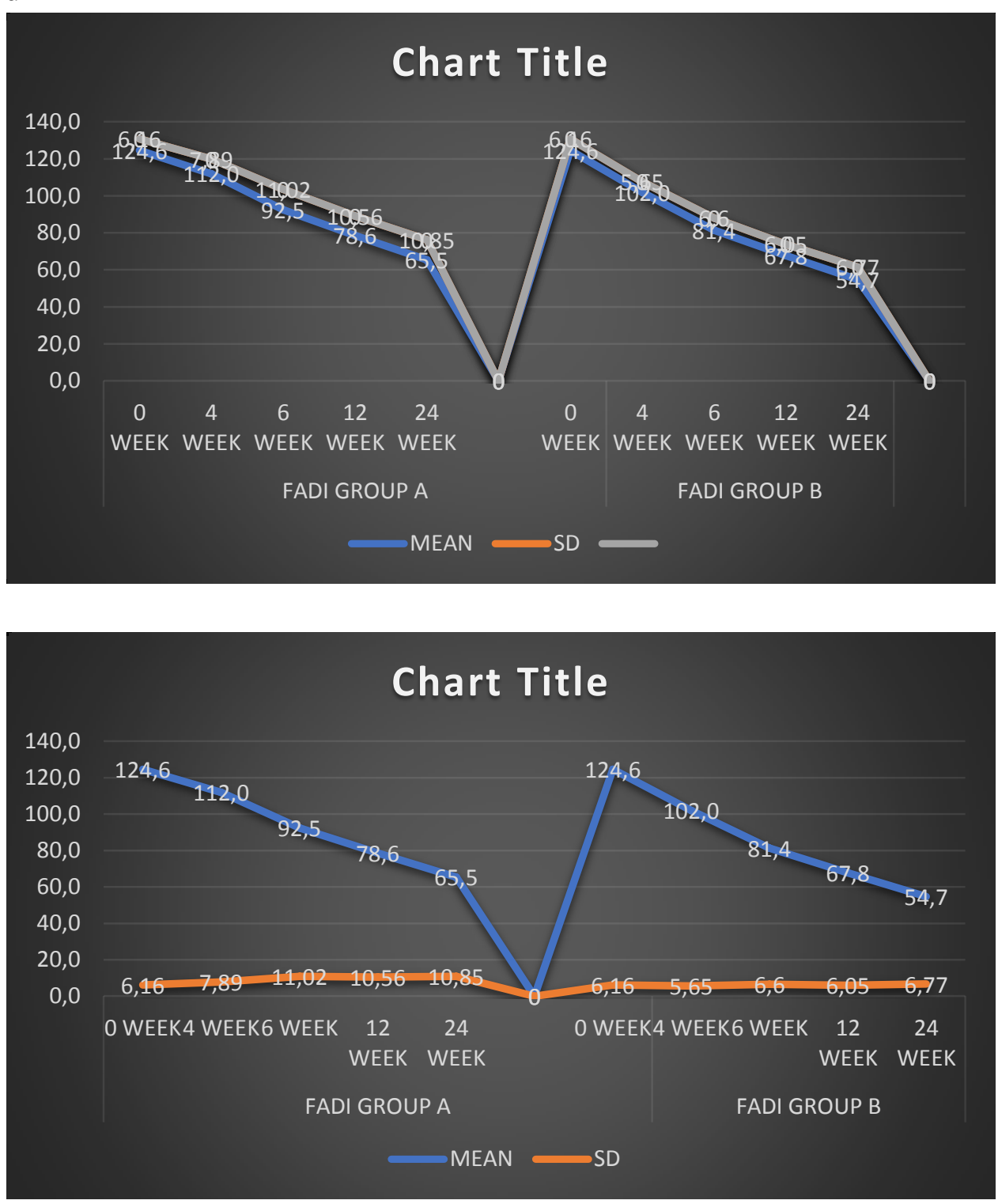

\begin{tabular}{|c|c|c|c|c|}
\hline Authors & Objectives & Design & Participants and Sample Size & Results \\
\hline $\begin{array}{l}\text { Adam Rowden } \\
\text { Dominici et al(2015) } \\
\text { Journal of Emergency } \\
\text { Medicine } 49(4), 546-551 \\
\text { [8] }\end{array}$ & $\begin{array}{l}\text { To determine patient } \\
\text { function among } \\
\text { patients randomized to } \\
\text { receive standard } \\
\text { therapy plus PRP, } \\
\text { compared to patients } \\
\text { who receive standard } \\
\text { therapy plus sham } \\
\text { injection (placebo). }\end{array}$ & $\begin{array}{l}\text { Prospective, } \\
\text { randomized, } \\
\text { double-blinded, } \\
\text { placebo-controlled } \\
\text { trial. }\end{array}$ & $\begin{array}{l}1156 \text { patients were screened } \\
\& 37 \text { were selected. } 18 \\
\text { randomized for PRP \& } 15 \text { for } \\
\text { placebo injection. Outcome } \\
\text { was measured by VAS \& } \\
\text { LEFS at } 0,3 \& 8 \text { days. Last } \\
\text { score was taken on } 30^{\text {th }} \text { day. } \\
\text { Patients were kept NWB for } 3 \\
\text { days }\end{array}$ & $\begin{array}{l}\text { In this small study, PRP did } \\
\text { not provide benefit in either } \\
\text { pain control or function over } \\
\text { placebo. }\end{array}$ \\
\hline $\begin{array}{l}\text { Lior Laver, McConket et } \\
\text { al(2015) } \\
\text { Knee Surgery, Sports } \\
\text { Traumatology, } \\
\text { Arthroscopy 23(11), } \\
\text { 3383-3392,2015 } \\
{[9]}\end{array}$ & $\begin{array}{l}\text { To compare effect of } \\
\text { PRP vs Placebo in } \\
\text { HIGH ANKLE } \\
\text { SPRAIN/Syndesmotic } \\
\text { sprain }\end{array}$ & $\begin{array}{l}\text { Prospective, } \\
\text { randomized, } \\
\text { double-blinded, } \\
\text { placebo-controlled trial }\end{array}$ & $\begin{array}{l}16 \text { elite athletes with AITFL } \\
\text { tears were randomized to a } \\
\text { treatment group receiving } \\
\text { injections of PRP or to a } \\
\text { control group. Patients were } \\
\text { prospectively evaluated for } \\
\text { clinical ability to return to full } \\
\text { activity and residual pain. } \\
\text { Dynamic USG was done for } \\
\text { stability }\end{array}$ & $\begin{array}{l}\text { Athletes suffering from high } \\
\text { ankle sprains benefit from } \\
\text { ultrasound-guided PRP } \\
\text { injections with a shorter } \\
\text { RTP, re-stabilization of the } \\
\text { syndesmosis joint and less } \\
\text { long term residual pain }\end{array}$ \\
\hline $\begin{array}{l}\text { Samra DJ, Sman AD, } \\
\text { Rae K, Linklater J, } \\
\text { Refshauge } \\
\text { Hiller.(1986) }\end{array}$ & $\begin{array}{l}\text { To determine whether a } \\
\text { single USG guided } \\
\text { PRP injection into the } \\
\text { anterior inferior }\end{array}$ & $\begin{array}{l}\text { Cohort controlled pilot } \\
\text { study }\end{array}$ & $\begin{array}{l}10 \text { Rugby Union players were } \\
\text { consented to receive a single } \\
\text { autologous PRP injection into } \\
\text { the AITFL within } 14 \text { days of }\end{array}$ & $\begin{array}{l}\text { A single autologous } \text { PRP } \\
\text { allows safe RTP with } \\
\text { improved } \\
\text { capacity. }\end{array}$ \\
\hline
\end{tabular}




\begin{tabular}{|c|c|c|c|c|}
\hline $\begin{array}{l}\text { American Journal of } \\
\text { clinical pathology } 85(1) \text {, } \\
50-56,1986 \\
{[10]}\end{array}$ & $\begin{array}{l}\text { tibiofibular ligament } \\
\text { (AITFL) reduces the } \\
\text { time for rugby athletes } \\
\text { to return to function } \\
\text { and match play } \\
\text { following } \\
\text { confirmed MRI } \\
\text { syndesmosis injury. }\end{array}$ & & $\begin{array}{l}\text { MRI confirmed ankle } \\
\text { syndesmosis injury. A } \\
\text { control group included } 11 \\
\text { comparable Rugby players } \\
\text { between who were treated } \\
\text { conservatively with the same } \\
\text { inclusion criteria and } \\
\text { rehabilitation protocol as the } \\
\text { intervention group. }\end{array}$ & \\
\hline $\begin{array}{l}\text { Victor Belda et al( 2002) } \\
\text { Knee Surgery, Sports } \\
\text { Traumatology, } \\
\text { Arthroscopy } \\
\text { 10, pages } 371-377(2002) \\
{[11]}\end{array}$ & $\begin{array}{l}\text { Treatment of complete } \\
\text { rupture of the lateral } \\
\text { ligaments of the ankle: } \\
\text { a randomized clinical } \\
\text { trial comparing cast } \\
\text { immobilization with } \\
\text { functional treatment }\end{array}$ & $\begin{array}{l}\text { randomized clinical } \\
\text { trial }\end{array}$ & $\begin{array}{l}\text { Patients were randomized } \\
\text { into an immobilization group } \\
\text { ( } 21 \text { days plaster cast) or a } \\
\text { functional one (15 days } \\
\text { strapping plus early } \\
\text { controlled mobilization). } \\
\text { Symptoms (pain, swelling, } \\
\text { stiffness, subjective } \\
\text { instability), joint laxity, return } \\
\text { to preinjury activity (time and } \\
\text { level) and rate of reinjury } \\
\text { were assessed } 3,6, \text { and } \\
12 \text { months after sprain }\end{array}$ & $\begin{array}{l}\text { The functional group } \\
\text { showed significantly earlier } \\
\text { and better return to physical } \\
\text { activity, fewer symptoms at } \\
3 \text { and } 6 \text { months but no } \\
\text { intergroup difference at } \\
12 \text { months. Functional } \\
\text { treatment also showed } \\
\text { better decrease in joint } \\
\text { laxity. No intergroup } \\
\text { differences were found in } \\
\text { the reinjury rate. conclude } \\
\text { that functional treatment is } \\
\text { safe, associated with a more } \\
\text { rapid recovery, and } \\
\text { particularly suitable in } \\
\text { athletic populations. }\end{array}$ \\
\hline $\begin{array}{l}\text { Blanco-Rivera } \\
\text { Elizondo-Rodriguez, } \\
\text { Simental-Mendia M, } \\
\text { Vilchez-Cavazos F, } \\
\text { Pena-Martinez et al. } \\
\text { Treatment of lateral } \\
\text { ankle sprain with } \\
\text { platelet-rich plasma: A } \\
\text { randomized clinical } \\
\text { study.Foot Ankle Surg. } \\
\text { 2019 Sep } \\
\text { [12] }\end{array}$ & $\begin{array}{l}\text { Treatment of lateral } \\
\text { ankle sprain with } \\
\text { platelet-rich plasma: }\end{array}$ & $\begin{array}{l}\text { A randomized clinical } \\
\text { study }\end{array}$ & $\begin{array}{l}21 \text { patients with grade II } \\
\text { lateral ankle sprain clinically } \\
\text { diagnosed were evaluated . A } \\
\text { rigid immobilization was } \\
\text { placed in all patients for ten } \\
\text { days; previously, an } \\
\text { application of PRP over the } \\
\text { anterior talofibular ligament } \\
\text { was performed in patients } \\
\text { from the experimental group. } \\
\text { The Visual Analogue Scale, } \\
\text { the American Orthopedic } \\
\text { Foot and Ankle Score, and the } \\
\text { Foot and Ankle Disability } \\
\text { Index were applied at } 3,5,8 \\
\text { and } 24 \text { weeks of follow-up } \\
\text { period }\end{array}$ & $\begin{array}{l}\text { he experimental group } \\
\text { presented the highest } \\
\text { reduction in pain and better } \\
\text { functional scores than the } \\
\text { control group at } 8 \text { weeks. At } \\
\text { the end of follow-up period } \\
\text { the results of both groups } \\
\text { were similar. }\end{array}$ \\
\hline
\end{tabular}

\section{Discussion}

Platelet rich plasma stimulate healing by clot formation. Thrombin at the site of bleeding causes platelet aggregation and activation, resulting in the release of alpha-granules, which contain growth factors that stimulate inflammatory cascade and promote healing.

Platelets encourage primary hemostasis via three major processes: activation, adhesion and aggregation. When the integrity of the vascular endothelium is interrupted, various macromolecular elements of the vascular subendothelium become exposed and readily accessible to platelets. ${ }^{[13]}$

The interaction of these growth factors are responsible for healing response, promoting chemotaxis,, cell proliferation, angiogenesis and collagen synthesis.

This pilot study is to highlight upon the fact that platelet rich plasma can be used in ligament tears as it has shown good improvement in terms of healing.

Clinicians should become aware of this therapy and more studies can be done in this.

PRP is proving to be promising modality for rehab \& safe RTP following ankle sprains. Further studies with longer follow ups, multi centre involvement \& larger no of subjects are needed to substantiate the result. ${ }^{[14]}$

The normal human platelet count ranges anywhere from 150,000 to $350,000 / \mu \mathrm{L}$. Improvements in bone and soft tissue healing have been 
demonstrated with concentrated platelets of up to $1,000,000 / \mu \mathrm{L}$, representing a three- to fivefold increase in growth factors. ${ }^{[15]}$

PRP allows faster healing of ligaments using body's own mechanism of inflammation \& healing. No adverse reactions are reported in most of studies. ${ }^{[17]}$

PRP doesn't violate the doping charter making it a safer option for athletes seeking safer RTP post injury. Recent studies on PRP do not demonstrate any performance enhancement beyond a potential therapeutic effect. ${ }^{[18]}$

Further research is requires to independently establish PRP as a treatment modality for ankle sprain.

\section{Summary and Conclusion}

This study is a prospective single centre randomized interventional study in which total 40 patients were selected from out patients departments of Sport's Injury Centre and divided in two equal groups using computerized block randomization. Group A received only conservative treatment including NSAIDS thome based exercises including ankle ROM and Strengthening exercise while Group B got additional intervention along with conservative treatment in form of PRP. Assessment was done at baseline(i.e. 0 week) and then after 4,6, 12 and 24 weeks after the intervention by using VAS and FADI score on all 4 follow ups. On comparing group $\mathrm{A}$ and $\mathrm{B}$, no statistically significant difference in VAS score found during $2^{\text {nd week }}$ but it become statistically significant at $4^{\text {th }}$ and $12^{\text {th }}$ and $24^{\text {th }}$ week between group A and group B. In the FADI scores statistically significant better results were noticed in the of group B from $4^{\text {th }}$ week and in every follow up over group A.

On the basis of this study we can conclude the following things:

1. Addition of PRP to the conservative treatment has a definite benefit in the management of ATFL tear.

2. Conservative treatment in addition to PRP for ATFL tear results in early relief in symptoms and ankle function started at 4 weeks as tested by FADI scale. So it can be considered as a good treatment option for ATFL tear.

3. In long term follow up i.e. of 12 weeks or more outcome measures were improved and much significant difference obtained in two groups.

4. For the research purpose PRP can also be added to see any synergy in outcomes.

5. A study with larger subjects, multicenter involvement with placebo comparison to be done so that results can be more optimized.

\section{References}

1. Mark Wai Wah Lai, Regina Wing Shan Sit. Healing of Complete Tear of the Anterior Talofibular Ligament and Early Ankle Stabilization after Autologous Platelet Rich Plasma: a Case Report and Literature Review.Arch Bone Jt Surg. 2018 Mar;6(2):146-149.

2. Hertel J. Functional Anatomy, Patho-mechanics and Pathophysiology of Lateral Ankle Instability. J Athl Train. 2002;37(4):364-375.

3. Hertel, J. Functional Instability Following Lateral Ankle Sprain. Sports Med. 2000; May;29(5):361-71.

4. Fan, Yijiao Fan, Karla Perez, Harry Dim. Clinical Uses of Platelet-Rich Fibrin in Oral and Maxillofacial Surgery. Dental Clinics. 2020 Apr;64(2):291-30

5. David Dohan Ehrenfest DM, Rasmusson L, Albrektsson T. Classification of platelet concentrates: from pure platelet-rich plasma (P-PRP) to leucocyte- and platelet-rich fibrin (L-PRF). Trends Biotechnol. 2009 March;27(3):158-167.

6. Marx Robert E. Platelet-Rich Plasma (PRP): What Is PRP and What Is Not PRP. DDS Implant Dentistry. 2001 December;10(4):225-228]

7. Engebretsen, Lars \& Steffen, Kathrin \& Alsousou, et al. IOC consensus paper on the use of platelet-rich plasma in sports 
medicine.British journal of sports medicine. 2010 Dec;44(15): 1072-81.

8. Rowden A, Dominici $P$, et al. Double-blind, Randomized, Placebo-controlled Study Evaluating the Use of Platelet-rich Plasma Therapy (PRP) for Acute Ankle Sprains in the Emergency Department. J Emerg Med. 2015 Oct;49(4):546-51.

9. Lior Laver, McConket et al. Knee Surgery Sports Traumatology Arthroscopy. Knee Surg Sports Traumatol Arthrosc .2015 Nov;23(11):3383-3392.

10. Samra DJ, Sman AD, Rae K, Linklater J, Refshauge KM, Hiller. Effectiveness of a single platelet-rich plasma injection to promote recovery in rugby players with ankle syndesmosis injury. American Journal of clinical pathology 1986;85(1): 50-56.

11. Ardevol J, Bolibar I, Belda V, Argilaga S. reatment of complete rupture of the lateral ligaments of the ankle: a randomized clinical trial comparing cast immobilization with functional treatment. Knee Surgery Sports Traumatology Arthroscopy. 2002 Nov;10:371-377.

12. Blanco-Rivera J, Elizondo-Rodriguez, Simental-Mendia M, Vilchez-Cavazos F, Pena-Martinez et al. Treatment of lateral ankle sprain with platelet-rich plasma: A randomized clinical study. Foot Ankle Surg. 2019 Sep;1268-7731(18):30140-1.
13. Mercy Halleluyah Periayah, Ahmad Sukari Halim, Arman Zahari Mat Saad. Mechanism Action of Platelets and Crucial Blood Coagulation Pathways in Hemostasis. Int J Hematol Oncol Stem Cell Res. 2017 Oct;11(4):319-327.

14. Adrian D.K. Le, Lawrence Enweze, Mlacolm R DeBaun, Jason L Dragon. Current Clinical Recommendations for Use of Platelet-Rich Plasma. Curr Rev Muculoskelet Med. 2018 Dec;11(4): 624-634.

15. Foster TE, Puskas BL, Mandelbaum BR, Gerhardt MB, Rodeo SA.Am J Sports Med. 2009 Nov;37(11):2259-72.

16. 16, Marx RE. Platelet-rich plasma (PRP): what is PRP and what is not PRP? Implant Dent. 2001;10:225-228.

17. Gabriela Fernandes, Shuying Yang. Application of platelet-rich plasma with stem cells in bone and periodontal tissue engineering. Bone Res.2016;4:16036.

18. WADA List of Prohibited Substance

19. Boesen AP, Hansen R, Boesen MI, Malliaras P, Langberg $\mathrm{H}$. Effect of high-volume injection, platelet-rich plasma, and sham treatment in chronic midportion achilles tendinopathy: a randomized double-blinded prospective study. Am J Sports Med. 2017;45: 2034-2043. 